\title{
Definiteness Effect (DE) in English as a Second Language
}

\author{
Meisam Rahimi \\ English Language Department, Faculty of Foreign Languages, University of Isfahan, Hezarjarib Ave., Isfahan, Iran \\ Manijeh Youhanaee \\ English Language Department, Faculty of Foreign Languages, University of Isfahan, Hezarjarib Ave., Isfahan, Iran
}

\begin{abstract}
The definiteness restriction or definiteness effect (DE) is one of the cross-linguistic variations, influencing the syntactic distribution of definites and indefinites. Generally speaking, sensitivity to definite determiner phrases (DPs) where definites are favored over indefinites is called definiteness effect and such an effect has been observed in a number of constructions (Abbott, 2006b).This study tries to take a look at the major lines of research with respect to the notion of definiteness and its effect (DE) in different languages as well as $\mathrm{L} 2$ studies which have focused on DE in second language acquisition. The paper raises a number of questions the investigation of which might shed some further light on the nature of L2 implicit knowledge and/or L2 linguistic processing.
\end{abstract}

Index Terms - definiteness, definiteness effect (DE), second language

\section{INTRODUCTION}

The claim as to the existence of various kinds of "existential constructions", with different conditions on the internal DP, is not new (Huang, 1987; Abbott, 1993; Li, 1996; Lambrecht, 2002; Paducheva, 2003; Beyssade, 2004; Leonetti, 2008). There are two basic ingredients required in dealing with DE: first, a theory of definiteness and second, some assumption concerning the conditions imposed on the postverbal DP by existential context. Accordingly, each of these elements is briefly reviewed first and then the studies conducted on DE in second language acquisition are introduced. Finally, this study raises a number of questions the investigation of which might illuminate further the nature of L2 implicit knowledge and/or L2 linguistic processing.

\section{DEFINITENESS}

It has been a matter of dispute as to what exactly differentiates definite from indefinite NPs. One tradition comes from Bertrand Russell's classic work on denoting phrases (Russell, 1905). According to Russell, it is uniqueness which distinguishes the from $a / a n$, that is, the existence of one and only one entity which meets the descriptive content of the NP. While Russell's analysis might seem to be applicable only to singular NPs, his concept can be extended to definite descriptions with plurals or mass heads (Hawkins, 1978). Russell also believed that both definite and indefinite NPs are quantificational expressions.

Russell's idea remained unchallenged for almost 50 years. However, since then a number of issues have caused many researchers to question or even reject it. For example, Strawson (1950), among others, believed that definite NPs are referential and that the uniqueness and existence of a referent is presupposed. Fewer researchers (e.g. Heim, 1982, 1983) also believe that indefinite NPs are referential. Another criticism against Russell's analysis is 'incomplete description' according to which in a great number of cases the descriptive content of a definite NP is not sufficient to single out a unique referent from the world on the whole. Two approaches have been proposed in dealing with this problem (Abbott, 2006b): A syntactic solution which proposes that "there is sufficient additional descriptive material tacitly present in the NP" (p. 393) and a more plausible approach which suggests that the uniqueness in definite NPs is to be understood relative to a context of utterance. These solutions, however, have been challenged (Abbott, 2006b; McCawley, 1979). Another approach has also been proposed by Lewis (1979). He claims that definite descriptions represent the most salient entity which meets the descriptive content.

The main competitor for the uniqueness approach to explaining the meaning of definiteness has been an approach in terms of familiarity or knownness (in Bolinger's terms, 1977). This approach is generally attributed to the Danish grammarian Paul Christophersen (1939). He claimed that what distinguishes definite from indefinite NPs is whether the hearer is supposed to be familiar with the referent of the NP. Heim $(1982,1983)$ also argued that a definite can only be used when the existence of the referent has been established in the particular discourse. While the familiarity notion can account for a number of uses of definite descriptions, there are cases where it seems that it cannot cover very well. For instance, there are cases where, regardless of the context, the descriptive content of the NP is sufficient to point out a unique referent. And even when the descriptive content is not sufficient, there are examples where the content of the 
sentence may single out a unique referent in context. Advocates of the familiarity theory often raise the idea of accommodation where the acceptance of a definite description by hearers depends on their ability to determine the intended referent.

While the prototypes of definiteness and indefiniteness in English are singular noun phrases (NPs) accompanied by the definite article the and the indefinite article a/an, these notions have been extended. From these two categories, definites have received rather more attention so that more than one researcher has characterized them by enumerating NP types (e.g. Westerståhl, 1985; Prince, 1992; Birner \& Ward, 1998; Ariel, 1988, 1990; for an extended list of definites and indefinites, refer to Abbott (2006a)).

There is no common agreement on the essence of definiteness or indefiniteness. Therefore, the need for some kind of diagnostic for these features has been felt. Many authors (Milsark 1974; Safir, 1985; Reuland \& ter Meulen, 1987; Lasnik, 1992, inter alia) have proposed that there is a definiteness restriction that inhibit the appearance of definite NPs in postverbal position in there constructions. Consequently, the definiteness effect, the ability of NPs to occur naturally in a locative existential, in existential constructions is usually considered one of the basic and the most direct way of assessing whether an expression is definite or not (Leonetti, 2008; Abbott, 2006b).

\section{DEFINITENESS EFFECT (DE)}

Certain constructions are usually characterized by a non-definiteness requirement on the theme argument, namely definiteness effect (DE). In other words, in some constructions sensitivity to definiteness, or more specifically to definite determiner phrases (DPs), has been observed across languages so that there is a tendency for definite DPs not to appear in these constructions. However, there are exceptions to this restriction where both definites and indefinites are allowed. There is evidence to believe that DE is present in some way in most, if not all, languages, although its manifestation may be obscured by a combination of lexical and syntactic factors (Leonetti, 2008).

In English, the DE occurs in a number of constructions. The construction with which the DE is typically associated in English is the existential construction (For the DE in have sentences refer to Tham (2006) and in attributive comparatives refer to Beil (1997)). These constructions start with an expletive (there) followed by a verb and a DP and sometimes a propositional phrase. The restriction is that a definite DP cannot typically appear in these constructions (with the exception of some certain cases) (details below).

As mentioned above, the DE is present in other languages of the world as well, such as Sardinian (Bentley, 2004), Chinese (Liejiong, 1995), Danish (Mikkelsen, 2002), Icelandic (Norris, 2011), Finnish (Chesterman, 2005), Korean (Chang \& Mikkelsen, 2005), Austronesian languages (Chung, 2008), Hungarian (Szabolcsi, 1984), Japanese (Kuroda, 2008), Italian and Catalan (Leonetti, 2008), Persian (Ghaniabadi, 2009) and Turkish (White, Belikova, Hagstrom, Kupisch \& Özçelik, 2012).

According to White et al. (2012), in languages without an expletive in existentials, it has been argued that an existential interpretation is only possible in a word order with the subject following the locative. On the other hand, in a word order where the locative comes after the subject, we will have a predicate locative (e.g. Freeze, 1992). However, White et al. (2012) believe that not only sentences with the locative first are existential but also existential interpretations are possible on constructions with the locative after the subject, as in Turkish and Russian.

\section{EXPLANATIONS FOR THE DE}

According to Leonetti (2008), there are currently two basic lines of thought with regard to the DE: the first one is based on the presuppositional nature of strong or definite determiners and the conflict between the felicity conditions ${ }^{1}$ for existential contexts and this presupposition (Lumsden 1988; Zucchi 1995); the other one is based on the nonreferential, property-denoting predicative nature of weak determiners, as a way of fulfilling the required conditions imposed by existentials (Milsark, 1977; McNally, 1992, 1998; Zamparelli, 1996; Van Geenhoven, 1998; Bende-Farkas \& Kamp, 2001; Landman, 2004).

Besides the above classification, there seem to be three basic trends of analysis in the literature, namely pragmatic, sematic and syntactic. Each of these trends is to be dealt with briefly in the following sections.

\section{A. Pragmatic}

Leonetti (2008) believes that the prevalence of DE in different languages of the world supports the accepted view that the phenomenon is a semantic/pragmatic constraint "involving something broader than grammatical definiteness" (Lyons 2003, p. 246). Leonetti (2008) believes that this restriction is derived from the principles of information structure, being "only a small part of a broader mechanism connecting reference and grammar" (159). Abbott (2006a), adopting a pragmatic perspective, also believes that the constraint cannot be expressed merely in terms of definiteness. Abbott believes that this is an illusion which is caused as a result of the close similarity of the constraint on the postverbal NP in a there-sentence and that on definiteness (Ward \& Birner, 1995; Birner \& Ward, 1998).

\footnotetext{
1 "the felicity conditions of there-sentences require that the common ground be neutral about the (non)emptiness of the intersection of the set denoted by the DP constituent with the set denoted by the coda" (Leonetti, 2008, p. 154)
} 
Although the pragmatic accounts of the DE differ in details, they all share the assumption that only DPs that do not presuppose the existence of their referents are accepted in existential constructions. It means that the subject must be non-anaphoric, in focus, hearer-new or novel $^{2}$ (e.g. Abbott, 1993; McNally, 1992; Rando \& Napoli, 1978; Ward \& Birner, 1995). Informally speaking, there is one essential requirement for DE in existential sentences and that is "that the referential or denotational properties of the internal DP are provided by the existential predicate, and cannot be independently obtained by the DP itself" (Leonetti, 2008, p. 133).

Specificity is a notion used by some researchers to account for the phenomenon. Adopting the notion of postspecificity from Wacha (1978), Szabolcsi (1983) tries to account for the observed exceptions in existentials. She considers the definite DPs which can appear in existentials as post-specific where they are not only introducing a new persistent discourse referent but also non-specific. Enç (1991), mentioning there-constructions in passing and presenting a pragmatically motivated account of specificity, also provides a pragmatic functional analysis of the DE. She equates strong DPs with specific ones where specificity is considered to be an information structural notion rather than truthconditional.

Peredy (2009) defines DE-constructions as "neutral, perfective sentences including a post-specific, or a definite but presentationally used internal argument” (p. 201). Going back to Hetzron's (1975) work, Peredy uses the term presentation to introduce "a new and persistent discourse referent without any reference to the definiteness or scope of the presented expression” (p. 202). She actually proposes an antilexicalist view towards presentation (introducing a discourse new entity) and definiteness effect by not holding any lexical requirement responsible for the phenomena. Agreeing with the types of links suggested by Enç (1991) between discourse referents and previously established discourse referents in definiteness and specificity and following Lambrecht (1994) in distinguishing the text internal and text external worlds, she defines specificity and definiteness with slight modification:

Specificity: A DP is specific iff its discourse referent is (assumed to be) linked to a previous discourse referent (i.e. linked discourse internally) by the inclusion relation (p. 213).

Definiteness: A DP is definite iff its discourse referent is (assumed to be) linked either to a previous discourse referent (i.e. discourse internally) or directly to a discourse external entity (via deixis or unique identification) by the identity relation (p. 213).

She believes that reference to a known but previously unmentioned entity (Deictic reference) establishes non-specific, but definite (i.e. discourse internally non-linked) reference. Consequently, the definite DPs of deictic constructions which are non-specific in this sense can be considered as post-specific ${ }^{3}$ (Peredy, 2009).

As mentioned above, pragmatic accounts of the DE all share the assumption that only DPs that do not presuppose the existence of their referents are accepted in existential constructions. However, White et al. (2012) argue that the absence of presupposition, although working for languages like English, cannot account for the restriction in languages like Turkish and Russian where definite expressions are permitted in negative existentials. In return, they propose a syntactic account of the DE, accounting for the restriction in those languages (see section 5.3).

\section{B. Semantic}

Another line of thought, started with Milsark (1977), is semantically based. Semantic accounts of the DE have centered on two cross-linguistic semantic properties consistently associated with existential constructions. The most important one is the DE on the DP and a second one is a restriction on the coda, asserting that the coda must describe an accidental property and not a permanent or essential property. In other words, it must be a stage-level predicate and not an individual-level predicate.

Semantic analysis, generally speaking, focuses on the kinds of determiners available in there-constructions. Milsark (1977) observed that while some English there-constructions prohibit the determiner phrase (DPs) which were called 'strong', others license the DPs which were called 'weak'. In a first step toward a more moderate information structural account, also accepted by Szabolcsi (1986), Barwise and Cooper (1981) concluded that strong determiners result in contradictions or tautologies rather than ungrammaticality.

Zucchi (1995) took the second step by defining strong determiners through the property of presuppositionality. Zucchi proposed Coda Condition according to which the domain of evaluation of there-sentences is provided by coda. This idea was formalized by Keenan $(2003)^{4}$. Zucchi and Keenan emphasize that since the determiner phrase and the coda do not form a constituent in syntax, their analysis is valid only on the level of semantics. In Zucchi's analysis strong determiners are strictly ungrammatical.

Purely semantic approaches (including Keenan), rule out the problematic cases in existentials (the appearance of definite DPs in existentials) via the radical assumption that strong determiners ${ }^{5}$ lead to ungrammatical sentences.

\footnotetext{
${ }^{2}$ This is also known as Novelty Condition.

3 "A DP is post-specific iff the discourse referent it introduces refers to an actual entity that is identified with an intentional one in the sentence" (Peredy, 2009, p 220).

${ }^{4}$ According to this formalization, weak determiners have the following property: for every $\mathrm{A}$ and $\mathrm{B}$ subset of the domain $\mathrm{E}: D\left(A_{2} B\right)=D(A \cap B, B)$.

${ }^{5}$ According to Keenan (2003), a determiner is strong if non-intersective. A determiner $D$ is intersective if for all A, A, $\mathrm{B}$ and $\mathrm{B}$ subsets of the domain $E$ : if $A \cap B=A^{E} \cap B^{\prime \prime}$ then $D\left(A_{3} B\right)=D\left(A_{2} B\right)$.
} 
Semantic accounts, as is the case for pragmatic explanations, appear no to be able to account for the cross-linguistic variation observed in negative existentials in Turkish and Russian (White et al., 2012).

\section{Syntactic}

Although syntactic accounts (notably, Safir, 1987) have generally been rejected in recent years, White et al., (2012) believe that the cross-linguistic differences observed can best be explained syntactically. However, asserting that there is no reason to consider only one kind of underlying explanation for the phenomenon, they believe that pragmatic and/or semantic explanations, along with syntactic accounts, can be the source of the DE. To this end, they assume that there is a close connection between syntactic structure and semantic interpretation. Following Diesing (1992), they consider a DP as indefinite if it is inside the domain of existential closure and vice versa. They argue that, in English existential constructions, subject DPs "cannot reach an interpretation position outside the domain of existential closure, and thus only DPs allowed within the domain of existential closure are allowed in existential constructions" (p. 83). And to account for the exceptions observed in Turkish and Russian negative existential, they attribute the availability of definite subject DPs in these constructions to the subject's escaping the domain of existential closure prior to interpretation.

\section{DEFINITENESS EFFECT IN ENGLISH}

Whereas the preposing of a discourse-old link through preposing constructions ${ }^{6}$ places relatively familiar information in preverbal position, postposing constructions ${ }^{7}$ present relatively unfamiliar information in postverbal position, hence preserving the old-before-new information-structure paradigm (Abbott, 2006a). These postposing constructions in English are represented by there-insertion existential sentences. The basic syntactic structure of these constructions is as follows:

$\left[\mathrm{IP} \cdots\left[\mathrm{vP} \mathrm{V}\left[\mathrm{DP}^{8}\right]\left[\mathrm{PP}^{9}\right]\right]\right.$

As can be seen the above representation, these constructions consist of four units: 'there', the verb, the determiner phrase and the adverbial represented by a PP. Two current typologies of these constructions are presented below.

In the first classification, Abbot (2006a) divides these constructions into two types, namely existential there and presentational there constructions where they move the canonical subject into postverbal position and fill the subject position by non-referential there, preserving the given-before-new information structure in cases where canonical word order would be otherwise. These constructions are similar in that they have both non-referential there in subject position while the canonical NP subject appears postverbally. Presentational there-insertion constructions ${ }^{10}$ differ from existential there constructions, however, in having verbs other than be (come, exist, die, etc.). Besides, the specifics of the constraint on the PVNP (postverbal noun phrase) in the two constructions differ slightly (Abbott, 2006a): Existential there requires PVNPs with hearer-new information, while presentational there requires PVNPs with discourse-new information.

As the second classification, Leonetti (2008) proposes that there are three basic types of existentials, each of which are explained briefly bellow. The first one is Proper or Pure existentials ${ }^{11}$. These sentences are the typical instance of rhematic/ thetic structures, they typically have a locative adjunct (which is not obligatory) and the interpretation of the internal DP does not depend on the contextual information from outside the construction (it does not have autonomous reference). The requirement of non-autonomous reference can be satisfied in two ways: first, by expressions, like indefinites, which only encode information about quantities and not any referential procedure and whose interpretation relies solely on the surrounding sentential elements and, second, by expressions, like definites, which, although encode some kind of referential procedure, do not rely on contextual information for their interpretation (they encode a uniqueness condition) but the linguistic information that is accessible in the sentence (the case of "weak" definites and "cataphoric" definites).

The second type is the eventive existential. These constructions include a small clause in which the DP acts like an internal topic. Instead of a new entity, they introduce a new event into the discourse where the event is presented as focal information. Obviously, in these constructions, the coda is obligatory. Both definites and indefinites are allowed in these constructions where they act as subjects of the embedded small clause, hence no definiteness effect is expected in them.

\footnotetext{
${ }^{6}$ The constructions that place canonically postverbal constituents in preverbal position, hence marking the preposed information as familiar within the discourse.

${ }^{7}$ The constructions that place canonically preverbal constituents in postverbal position, hence mark the postposed information as new.

${ }^{8}$ The DP is sometimes referred to as the 'pivot'

${ }^{9}$ The phrase is usually referred to as 'coda'

${ }^{10}$ In this construction, There can have a second referential reading where it will receive an $\mathrm{H}^{*}$ pitch accent and will be coreferential with the place in the previous discourse.

${ }^{11}$ These constructions are also called locative existentials. In these constructions, the prepositional phrase following the focus NP is a separate constituent which locates the item in question (Abbott, 2006b).
} 
Finally, the third type is the enumerative existential. These constructions have a classical "reminder" or "list" 12 reading (Rando \& Napoli, 1978). In these constructions, definite DPs are allowed, the coda is absent or implicit and there is no definiteness effect.

\section{DEFiniteness EfFect In ENGLish AS A SECOND LANGUAGE}

There has been relatively little examination of the L2 acquisition of the DE (White et al., 2012). The research has mostly been conducted on spontaneous or relatively spontaneous production data. White (2003), in a case-study of an adult native speaker of Turkish learning English as a second language, reported no DE violations, although the subject did make errors in the form of article omission. Lardiere (2004), in a case-study of a steady-state L2 speaker of Chinese (a language without articles), also found no DE violations. White (2008) conducted another study on intermediate level Turkish-speaking and Chinese-speaking English learners through elicited production data. In this study again, she did not report any DE violations. And in the most recent study, White et al. (2012) investigated whether native Turkish and Russian L2 learners of English in advanced and intermediate levels of proficiency show knowledge of definiteness effect or not. To this end, they devised an acceptability judgment task where the subjects were required to judge some contextualized sentences as natural or unnatural. The results of the study showed that learners in both levels responded the items like English native speakers, hence having acquired the DE in English.

Some recent studies have tried to find out whether there are any ERP effects relating to the DE. King, Steinhauer and White (2006) conducted an ERP study to investigate the DE in low and high intermediate Chinese-speaking L2 learners of English through a grammaticality judgment test. According to the result, the low intermediate subjects did not show any signs of the acquisition of the DE and no ERP effects were also reported. On the other hand, the high intermediate learners, distinguished between DE violations and equivalent grammatical sentences and P600 effects ${ }^{13}$ were reported as well. Drury, E. White, L. White and Steinhauer (2009) similarly investigated the DE in advanced and low proficiency native French and Chinese L2 learners of English. While they found evidence for P600 effects in advanced learners, no such effect could be found in low proficiency groups.

In summary, the results from previous studies suggest that second language learners become sensitive to definiteness restriction in English as their linguistic competence grows more and more.

\section{CONCLUSION}

Leonetti (2008) believes that the origin of the DE cannot be simply associated with some conditions, such as the Novelty Condition, regarding there-insertion constructions. He asserts that a number of factors are to be taken into consideration in the DE: (a) the role of the internal structure of the existential construction, particularly the role of coda in final position; (b) the effects of various lexical predicates competing for conveying presentative or existential meanings; (c) the possibility that the existential verbs cancel the conditions for the DE through selecting an eventive small clause and finally (d) attributing the contrasts linked to the DE both in existential sentences and in inverted subject constructions to the crosslinguistic variation in information packaging and Focus structure. Accordingly, much work is still needed to develop a theory which ties all these factors together (Leonetti, 2008).

Considering the studies on the DE in second language, a question could be posed, suggesting the need for further investigation on the DE in second language acquisition. Considering the general structure of there-insertion existentials (see section 4), other existential verbs (unaccusative verbs) than the typical be are allowed in these constructions. While these constructions with these verbs are grammatically well-formed, they are much less frequent than the typical verb be. Theoretically speaking, language learners who have acquired the DE are expected to distinguish between DE violations and equivalent grammatical sentences in these cases, that is, existential constructions with unaccusative verbs. Practically speaking, on the other hand, L2ers might not be able to distinguish between the two. In this case, the failure can be attributed to the nature of our implicit linguistic knowledge and the related cognitive processing than the notion of definiteness or definiteness effect.

\section{REFERENCES}

[1] Abbott, B. (2006a). Definiteness and Indefiniteness. In L. R. Horn \& G. Ward (eds.), The handbook of pragmatics. MA, Malden: Blackwell Publishing.

[2] Abbott, B. (2006b). Definite and Indefinite. In K. Brown (ed.), Encyclopedia of language and linguistics (14-Volume Set, 2ed edn.). US, Boston: Elsevier.

[3] Abbott, B. (1993). A pragmatic account of the definiteness effect in existential sentences. Journal of Pragmatics 19, 39-55.

[4] Ariel, M. (1988). Referring and accessibility. Journal of Linguistics 24, 65-87.

[5] Ariel, M. (1990). Accessing Noun Phrase Antecedents. London: Routledge.

[6] Barwise, J. \& R. Cooper. (1981). Generalized quantifiers and natural language. Linguistics and Philosophy 4, 159-219.

\footnotetext{
${ }^{12}$ Also called list existentials, these constructions are typically used to offer entities which fulfill some role or purpose (Abbott, 2006b). These constructions do not permit the focus NP to be followed by a locative prepositional phrase. However, the NP modifier prepositional phrases are allowed.

${ }^{13}$ These effects are generally associated with the recognition of grammaticality violations.
} 
[7] Beil, F. (1997). The definiteness effect in attributive comparatives. In Proceedings of SALT (pp. 37-54).

[8] Bende-Farkas, A. \& H. Kamp (2001). Indefinites and binding: From specificity to incorporation. In 13th European summer school in logic, language and information.

[9] Bentley, D. (2004). Definiteness effects: evidence from Sardinian. Transactions of the Philological Society 102.1, 57-101.

[10] Beyssade, C. (2004). Les constructions existentielles. In C. Dobrovie-Sorin \& C. Beyssade (eds.), Définir les indéfinis. Paris: CNRS.

[11] Birner, B. J. \& G. Ward. (1998). Information Status and Noncanonical Word Order in English. Amsterdam, Netherlands: Benjamins.

[12] Bolinger, D. (1977). “There.” In D. Bolinger \& D. Le Merton Bolinger (eds.), Meaning and Form (90-123). London: Longman.

[13] Chang, C. \& L. Mikkelsen. (2005). On existentials, locatives, and the definiteness effect in Korean. Unpublished manuscript, University of California, Berkeley.

[14] Chesterman, A. (2005). On definiteness a study with special reference to English and Finnish. UK: Cambridge University Press.

[15] Christophersen, P. (1939). The Articles: A Study of Their Theory and Use in English. Copenhagen, Denmark: Munksgaard.

[16] Chung, S. (2008). Possessors and definiteness effects in two Austronesian languages. In L. Matthewson (ed.), Quantification: A cross-linguistic perspective (179-224). Boston, MA: Brill Academic Publishing.

[17] Diesing, M. (1992). Indefinites. Cambridge, MA: M.I.T. Press.

[18] Drury, J., E. White, L. White \& K. Steinhauer. (2009). Brain potentials and the processing of (in) definiteness in late learners of English. Poster presented at the Cognitive Neuroscience Society, San Francisco.

[19] Enç, M. (1991). The semantics of specificity. Linguistic Inquiry 22, 1-27.

[20] Freeze, R. (1992). Existentials and other locatives. Language 68, 553-595.

[21] Ghaniabadi, S. (2009). Definiteness marking through number. In Proceedings of the 2009 Annual Conference of the Canadian Linguistic Association. Retrieved from: http://homes. chass. utoronto. ca/ cla-acl/actes2009/actes2009. html (accessed 05/5/2013).

[22] Hawkins, J. A. (1978). Definiteness and Indefiniteness. Atlantic Highlands, NJ: Humanities Press.

[23] Heim, I. (1982). The semantics of definite and indefinite noun phrases. Ph.D. diss., University of Massachusetts.

[24] Heim, I. (1983). 'File change semantics and the familiarity theory of definiteness.' In B. Rainer, C. Schwarze \& A. Von Stechow (eds.) Meaning, use and the interpretation of language (164-189). Berlin, Germany: Walter de Gruyter.

[25] Hetzron, R. (1975). The presentative movement, or why the ideal word order is V.S.O.P. In C. Li (ed.), Word order and word order change (345-388). Austin: University of Texas Press.

[26] Huang, C. T. J. (1987). Existential sentences in Chinese and (in)definiteness. In E. J. Reuland \& A. GB Ter Meulen, The Representation of (In)definiteness (eds.). Cambridge MA: The MIT Press.

[27] Keenan, E. L. (1987). A semantic definition of "Indefinite NP'. In E. J. Reuland \& A. GB Ter Meulen (eds.), The Representation of (In)definiteness (286-317). Cambridge MA: The MIT Press.

[28] Keenan, E. L. (2003). The definiteness effect: semantics or pragmatics? Natural Language Semantics 11, 187-216.

[29] King, E., K. Steinhauer \& L. White. (2006). The definiteness effect in L2 acquisition: What can event-related brain potentials tell us? Paper presented at Generative Approaches to Second Language Acquisition 8, Banff.

[30] Kuroda, S.-Y. (2008). Head Internal Relative Clauses, Quantifier Float, the Definiteness Effect and the Mathematics of Determiners. San Diego Linguistics Papers 3, 126-183.

[31] Lambrecht, K. (1994). Information Structure and Sentence Form. Cambridge: Cambridge University Press.

[32] Lambrecht, K. (2002). Topic, focus and secondary predication. The French presentational relative construction. In C. Beyssade, R. Bok-Bennema, F. Drijkoningen \& P. Monachesi (eds.), Romance Languages and Linguistic Theory 2000 (171-212). Amsterdam: John Benjamins.

[33] Landman, F. (2004). Indefinites and the Type of Sets. Oxford, UK: Blackwell.

[34] Lardiere, D. (2004). Knowledge of definiteness despite variable article omission in second language acquisition. In A. Brugos, L. Micciulla \& C.E. Smith (eds.), Proceedings of the 28th Annual Boston University Conference on Language Development (pp. 328-339). Somerville, MA: Cascadilla Press.

[35] Lasnik, H. (1992). Case and expletives: notes toward a parametric account. Linguistic Inquiry 23, 381-405.

[36] Leonetti, M. (2008). Definiteness effects and the role of the coda in existential constructions. In H. H. Müller \& A. Klinge (eds.). Essays on Nominal Determination: From morphology to discourse management. Amsterdam, Netherlands: John Benjamins Publishing Company.

[37] Lewis, D. (1979). Scorekeeping in a language game. Journal of Philosophical Logic 8, 339-59.

[38] Li, Y.-A. (1996). Definite and indefinite existential constructions. Studies in the Linguistic Sciences 26.2, $175-191$.

[39] Liejiong, X. (1995). Definiteness effects on Chinese word order. Cahiers de linguistique- Asia orientale 24.1, 29-48.

[40] Lumsden, M. (1988). Existential Sentences: Their Structure and Meaning. London, UK: Croom Helm.

[41] Lyons, J. (2003). Definiteness. UK: Cambridge University Press.

[42] McCawley, J. D. (1979). 'Presupposition and discourse structure.' In C.-K. Oh and D. A. Dinneen (eds.), Syntax and semantics: Presupposition (371-388). New York, N.Y.: Academic Press.

[43] McNally, L. (1992). An Interpretation for the English Existential Construction. PhD dissertation, University of California at Santa Cruz. (Published as A Semantics for the English Existential Construction. New York NY: Garland, 1997).

[44] McNally, L. (1998). Existential sentences without existential quantification. Linguistics and Philosophy 21, $353-392$.

[45] Mikkelsen, L. (2002). Reanalyzing the definiteness effect: Evidence from Danish. Working papers in Scandinavian syntax 69, $1-75$.

[46] Milsark, G. (1977). Toward an explanation of certain peculiarities of the existential construction in English. Linguistic Analysis 3, 1-29.

[47] Milsark, G. (1974). Existential Sentences in English. PhD dissertation, MIT. Distributed by the Indiana University Linguistics Club. 
[48] Norris, M. (2011). Extraposition and Definiteness Effects in Icelandic DPs. UC Santa Cruz: Linguistics Research Center. Retrieved from: http://escholarship.org/uc/item/95z0h8km (accessed 01/5/2013).

[49] Paducheva, E. (2003). Definiteness effect: The case of Russian. In K. Von Heusinger \& U. Egli (eds.), Reference and Anaphoric Relations (133-146). Dordrecht, Netherlands: Kluwer.

[50] Peredy, M. (2009). Obligatory adjuncts licensing Definiteness Effect constructions. In A. Alexiadou \& T. A. Hall (eds.), Adverbs and Adverbial Adjuncts at the Interfaces. Berlin, Germant: Mouton de Gruyter.

[51] Prince, E. F. (1992). The ZPG Letter: subjects, definiteness, and information-status. In W. C. Mann \& S. A. Thompson (eds.), Discourse Description: Diverse linguistic Analyses of a Fundraising Text (295-325). Amsterdam, Netherlands: John Benjamins Publishing.

[52] Rando, E. \& D.J. Napoli. (1978). Definites in there-sentences. Language 54, 300-313.

[53] Reuland, E. J. \& A. G. Ter Meulen. (1987). The Representation of (In) definiteness. Cambridge, MA: MIT Press.

[54] Russell, B. (1905). On denoting. Mind 14, 479-93.

[55] Safir, K. (1985). Syntactic Chains. UK: Cambridge University Press.

[56] Safir, K. (1987). What explains the definiteness effect? In E. J. Reuland \& A. GB Ter Meulen (eds.), The Representation of (In) definiteness (pp. 71-97). Cambridge MA: The MIT Press.

[57] Strawson, P. F. (1950). On referring. Mind 59, 320-44.

[58] Szabolcsi, A. (1983). A specifikus/nem-specifikus megküö lönbö ztetésról [About the specific/ non-specific distinction]. Nyelvtudoma'nyi Közleme'nyek 85, 83-92.

[59] Szabolcsi, A. (1984). From the definiteness effect to lexical integrity. In W. Abraham \& S. de Meij (eds.), Topic, Focus, and Configurationality (321-348). Amsterdam: John Benjamins.

[60] Szabolcsi, A. (1986). From the definiteness effect to lexical integrity. In W. Abraham \& S. de Meij (eds.), Topic, Focus, and Configurationality (321-348). Amsterdam, Netherlands: John Benjamins.

[61] Tham, S. W. (2006). The Definiteness Effect in English Have Sentences. In P. Denis, E. McCready, A. Palmer \& B. Reese (eds.), Proceedings of the 2004 Texas Linguistics Society Conference (137-149). Somerville, MA: Cascadilla Proceedings Project.

[62] Van Geenhoven, V. (1998). Semantic Incorporation and Indefinite Descriptions. Stanford CA: CSLI.

[63] Wacha, B. (1978). Az igés-szerkezeti aspektus kategó riája a magyar nyelvben [The category of verbal aspect in Hungarian], Ph. D. diss., Szombathely.

[64] Ward, G. \& B. J. Birner. (1995). Definiteness and the English existential. Language 71, 722-42.

[65] Westerståhl, D. (1985). Determiners and context sets. In V. Benthem, J. FAK (eds.), Generalized quantifiers in natural language (45-72). Berlin, Germany: Walter de Gruyter.

[66] White, L. (2003). Fossilization in steady state L2 grammars: Persistent problems with inflectional morphology. Bilingualism: Language and Cognition 6, 129-141.

[67] White, L. (2008). Definiteness effects in the L2 English of Mandarin and Turkish speakers. In H. Chan, H. Jacob \& Enkeleida Kapia (eds.), Proceedings of the 32nd Annual Boston University Conference on Language Development (pp. 550-561). Somerville, MA: Cascadilla Press.

[68] White, L., A. Belikova, P. Hagstrom, T. Kupisch \& Ö Özçelik. (2012). Restrictions on definiteness in second language acquisition: Affirmative and negative existentials in the L2 English of Turkish and Russian speakers. Linguistic Approaches to Bilingualism, 2(1), 54-89. doi 10.1075/lab.2.1.03whi.

[69] Zamparelli, R. (1996). Layers in the Determiner Phrase. PhD dissertation, University of Rochester.

[70] Zucchi, S. (1995). The ingredients of definiteness and the Definiteness Effect. Natural Language Semantics 3, $33-78$.

Meisam Rahimi was born in Isfahan, Iran on March 14, 1983. He received his BA degree in English language and Literature from the University of Isfahan, Isfahan, Iran in 2008. He is currently an MA student in Teaching English as a Foreign Language (TEFL) at the University of Isfahan. His areas of interest include language acquisition and computational linguistics.

Manijeh Youhanaee holds a PhD in language and linguistics from the University of Essex. She has co-authored with Badrizadeh “A Descriptive Dictionary of Theories of Generative Grammar". She has published a number of articles on the teaching/ acquisition of different English syntactic properties by native speakers of Persian. She teaches MA and PhD courses in linguistics, generative grammar, TEFL and SLA. Her areas of interest include syntactic theory, acquisition of L2 \& L3 syntax and issues in teaching and learning English as a second/foreign language. 